\title{
ANALISIS FAKTOR-FAKTOR YANG MEMPENGARUHI KEUNTUNGAN USAHATANI KELAPA SAWIT (SWADAYA MURNI)DI KECAMATAN JAMBI LUAR KOTA KABUPATEN MUARO JAMBI
}

\author{
Ridho Iskandar ${ }^{1)}$, Saidin Nainggolan ${ }^{2)}$ dan Emy Kernalis ${ }^{2)}$ \\ 1) Alumni Jurusan Agribisnis Program Studi Agribisnis Fakultas Pertanian Unja \\ ${ }^{2)}$ Staf Pengajar Jurusan Agribisnis Fakultas Pertanian Unja \\ Email: Ridhoiskandar307@yahoo.com
}

\begin{abstract}
ABSTRAK
Penelitian ini bertujuan untuk mengetahui (1) Untuk mengetahui besarnya struktur biaya dan keuntungan yang diperoleh dari usahatani kelapa sawit swadaya murni di Kecamatan Jambi Luar Kota Kabupaten Muaro Jambi (2) Untuk mengetahui faktor-faktor apa saja yang mempengaruhi keuntungan usahatani kelapa sawit swadaya murni di Kecamatan Jambi Luar Kota Kabupaten Muaro Jambi. Metode analisis data yang digunakan dalam analisis ini adalah analisis Deskriftif Kuantitatif yaitu analisis keuntungan yang terdiri dari analisis penerimaan dan biaya produksi untuk usahatani kelapa sawit (swadaya murni). Untuk menganalisis faktor-faktor yang mempengaruhi keuntungan usahatani kelapa sawit (swadaya murni) digunakan metode Analisis Regresi Linier Berganda. Penelitian ini dilaksanakan pada tanggal 01 November 2015 sampai dengan 01 Desember 2015. Hasil penelitian ini menunjukan (1) rata-rata biaya yang dikeluarkan oleh petani sebesar Rp.33.154.125/tahun dan rata- rata biaya yang dikeluarkan oleh petani per hektarnya sebesar Rp.9.688.247/Ha/tahun. Rata-rata keuntungan usahatani kelapa sawit (swadaya murni) sebesar Rp.51.541.875/tahun dan rata-rata keuntungan usahatani kelapa sawit (swadaya murni) per hektarnya sebesar Rp.15.641.177/Ha/Tahun. (2) faktor biaya pupuk urea, biaya pupuk lain, biaya tenaga kerja, luas lahan dan umur tanaman (dummy) secara bersamasama berpengaruh sangat nyata terhadap keuntungan usahatani kelapa sawit (swadaya murni) di daerah penelitian. Sedangkan secara parsial biaya pupuk urea dan biaya pupuk lain (non urea) berpengaruh negatif terhadap keuntungan usahatani kelapa sawit swadaya murni. Dari hasil penelitian diharapkan Perlu adanya bantuan oleh pemerintah, sehingga petani mampu memperluas usahatani kelapa sawitnya
\end{abstract}

Kata kunci : Keuntungan, Usahatani Kelapa Sawit, dan Faktor Produksi

\section{ABSTRACT}

This research is to know (1) the structure of costs and benefits of oil palm farming (pure self) in Jambi Luar Kota district Muaro Jambi regency (2) the factors that affect farm profits palm pure self in in Jambi Luar Kota district Muaro Jambi regency. Data confected in this research in analyzed this data analize used methode used in quantitative descriptive method that is The advantage analysis for oil palm farming (pure self). To analyze the factors that affect farm profits palm oil (pure self) used multiple linear regression analysis method. This research in 01 November 2015 untill 01 December 2015. The results of this research indicate (1) the average costs of farmers is Rp. Rp.33.154.125/year and the average costs of farmer per hectare of Rp. Rp.9.688.247/Ha/year. the average profits of farming the oil palm farming (pure self) is Rp.51.541.875/year and the average profits of farming the oil palm farming (pure self) per hectare of Rp.15.641.177/Ha/year. (2) Factors ofcost of urea fertilizer, other fertilizer costs, the cost of labor, land area, and plan age (dummy) in the real profits of farming the oil palm farming (pure self)in the research area. While partially the cost of urea fertilizer and other fertilizer costs (non urea) has negative effect in the profits of farming of oil palm farming (pure self). From this research the expectation to help by local government, so that the farmer is able to expand the oil palm farming.

Keyword: Profits, oil palm farming, and Factor of production 


\section{PENDAHULUAN}

Subsektor perkebunan di Indonesia pada saat ini masih memegang peranan penting bagi kehidupan masyarakat, karena subsektor perkebunan disamping memberikan dukungan langsung terhadap perekonomian rakyat juga berfungsi dalam penyediaan lapangan pekerjaan, menghasilkan bahan baku industri dan memberikan devisa negara yang cukup besar melalui ekspor. Subsektor perkebunan dalam perekonomian nasional juga berperan sebagai sektor pendukung bagi sektor lainnya terutama sektor industri yaitu industri pengolahan. Luas areal perkebunan kelapa sawit di Indonesia selama tujuh tahun terakhir cenderung menunjukkan peningkatan, naik sekitar 2,49 s.d. 11,33 persen per tahun. Pada tahun 2008 lahan perkebunan kelapa sawit Indonesia tercatat seluas 7,33 juta hektar, meningkat menjadi 10,13 juta hektar pada tahun 2012. Pada tahun 2013 luas areal perkebunan kelapa sawit masih meningkat sebesar 4,47 persen dari tahun 2012 menjadi 10,59 juta hektar dan di tahun 2014 diperkirakan meningkat sebesar 2,49 persen menjadi 10,85 juta hektar (Statistik Kelapa Sawit Indonesia, 2013 ). Berdasarkan data Dinas Perkebunan Provinsi jambi, tanaman kelapa sawit merupakan salah satu komoditi perkebunan yang memiliki arti ekonomi dan sosial bagi masyarakat khususnya masyarakat provinsi Jambi. Hal ini dibuktikan dengan luas areal tanaman dan produksi kelapa sawit yang terus mengalami peningkatan setiap tahunnya.

Perkembangan luas lahan perkebunan kelapa sawit di Provinsi Jambi tidak terlepas dari perkembangan luas lahan perkebunan kelapa sawit di Kabupaten. Pada saat ini, hampir disetiap kabupaten di Provinsi Jambi memiliki lahan kelapa sawit. Kabupaten Muaro Jambi merupakan sentral produksi kelapa sawit terbesar di Provinsi Jambi, yaitu dengan produksi sebanyak 338.781 ton dengan luas areal 130,9 ribu Ha.perkebunan kelapa sawit di Kabupaten Muaro Jambi ini terbagi atas dua yaitu perkebunan besar negara dan swasta, serta perkebunan rakyat. Sedangkan untuk pola pengusahaannya terbagi atas plasma PIR dan Swadaya murni, dapat dilihat perbedaan luas lahan dan produksi yang cukup besar antara usahatani kelapa sawit swadaya murni dan plasma PIR. Luas usahatani kelapa sawit swadaya murni di Kabupaten Muaro Jambi yaitu sebanyak $25,11 \%$ dari total luas perkebunan kelapa sawit di Kabupaten Muaro Jambi, dimana luas areal usahatani kelapa sawit swadaya murni sebesar $32.867 \mathrm{Ha}$ dengan produksi sebesar 63.510 ton. Sedangkan untuk Plasma PIR luas areal sebesar 59.098 Ha dengan produksi sebesar 172.731 ton.

Perkembangan luas lahan kelapa sawit di Kabupaten Muaro Jambi tidak terlepas dari perkembangan luas lahan kelapa sawit di setiap Kecamatan dalam Kabupaten Muaro Jambi. Kecamatan Jambi Luar Kota merupakan daerah yang memiliki sentra produksi kelapa sawit di Kabupaten Muaro Jambi. Hal ini juga dapat dilihat dari jumlah luas areal dan jumlah produksi, Kecamatan Jambi Luar Kota menempati peringkat keempat terbanyak setelah Kecamatan Sekernan, Sungai Bahar dan Muaro Sebo dalam hal pengusahaan perkebunan kelapa sawit swadaya murni dengan luas areal sebesar 4.842 Ha dan jumlah produksi sebesar 16.350 ton. Namun dari jumlah tanaman menghasilkan Kecamatan Jambi Luar Kota terbanyak kedua setelah Kecamatan Sungai Bahar dengan luas areal tanaman menghasilkan sebesar $4.330 \mathrm{Ha}$. Dari jumlah produktivitas Kecamatan Jambi Luar Kota merupakan daerah dengan produktivitas tertinggi di Kabupaten Muaro Jambi yaitu sebesar $3.776 \mathrm{~kg} / \mathrm{Ha}$, berbanding jauh dengan Kecamatan Sungai Bahar yang memiliki areal tanaman menghasilkan terbesar namun dari segi produktivitas hanya sebesar $2.943 \mathrm{Kg} / \mathrm{Ha}$. Oleh karena itu, diperkirakan hal tersebut dapat mempengaruhi jumlah pendapatan yang diterima petani di Kecamatan 
Jambi Luar Kota dari hasil usaha perkebunan kelapa sawit tersebut. Selain itu, keragaman umur tanaman kelapa sawit yang diusahakan petani di Kecamatan Jambi Luar Kota bervariasi, hal ini dikarenakan banyak petani yang mengalih fungsi usahatani karet menjadi usahatani kelapa sawit.Kecamatan Jambi Luar Kota merupakan salah satu kecamatan yang mengusahakan perkebunan kelapa sawit swadaya murni yang cukup potensial hal ini ditunjukkan dengan jumlah produksi yang cukup besar yaitu 16,3 ribu ton per tahun. Usaha perkebunan kelapa sawit di Kecamatan Jambi Luar Kota memiliki tujuan yang sama dengan usaha lainnya yaitu untuk memperoleh penerimaan lebih besar dari pada total biaya yang dikeluarkan selama proses produksi. Petani swadaya (perorangan) dalam membangun kebunnya secara langsung bersumber dari dana sendiri tanpa dibantu oleh pihak lain. Memperoleh sarana produksi seperti pupuk, obat-obatan, peralatan, juga disediakan dari petani sendiri. Dalam hal pemasaran, petani swadaya menjual hasil kebunnya langsung ke pedagang pengumpul atau pabrik sesuai yang mereka inginkan. Secara umum dapat dikatakan bahwa faktor-faktor yang mempengaruhi keuntungan adalah harga, jumlah produksi, biaya pupuk, biaya tenaga kerja, luas lahan dan umur tanaman. Telah dijelaskan bahwa luas lahan Petani kelapa sawit swadaya di Kecamatan Jambi Luar Kota adalah terbesar keempat, namun dari segi produksi merupakan daerah sentral kedua setelah Kecamatan Sungai Bahar sedangkan dari segi produktivitas Kecamatan Jambi Luar Kota merupakan kecamatan dengan Produktivitas tertinggi di Kabupaten Muaro Jambi. Sejalan dengan hal tersebut tentunya berdampak terhadap besar kecilnya penerimaan yang diterima oleh petani, karena semakin besar produksi yang dihasilkan maka semakin besar pula keuntungan yang akan diterima oleh petani. Petani sebagai pelaksana mengharap produksi yang lebih besar lagi agar memperoleh pendapatan yang besar pula. Petani menggunakan tenaga, modal dan sarana produksinya sebagai umpan untuk mendapatkan produksi yang diharapkan. Suatu usahatani dikatakan berhasil apabila usahatani tersebut dapat memenuhi kewajiban membayar bunga modal, alat yang digunakan, upah tenaga luar serta sarana produksi lainnya (Suratiyah, 2011)

Berdasarkan latar belakang dan permasalahan maka penelitian ini bertujuan untuk mengetahui (1) Untuk mengetahui besarnya struktur biaya dan keuntungan yang diperoleh dari usahatani kelapa sawit swadaya murni di Kecamatan Jambi Luar Kota Kabupaten Muaro Jambi (2) Untuk mengetahui faktor-faktor apa saja yang mempengaruhi keuntungan usahatani kelapa sawit swadaya murni di Kecamatan Jambi Luar Kota Kabupaten Muaro Jambi.

\section{METODE PENELITIAN}

Penelitian ini dilaksanakan di Kecamatan Jambi Luar Kota yang berdasarkan data tahun 2014 Kecamatan Jambi Luar Kota terdiri dari 20 desa. Penarikan sampel desa dipilih secara sengaja (purposive) 2 desa dari 20 desa yaitu Desa Muhajirin dan Kelurahan Pijoan. Dengan pertimbangan Desa Muhajirin dan Kelurahan Pijoan merupakan desa yang memiliki luas areal terbesar dan memiliki jumlah petani terbanyak dibandingkan dengan petani di Desa lainnya. Untuk masing-masing desa diambil presisi sebesar $15 \%$, secara lebih terperinci dimana jumlah petani di Desa Muhajirin adalah sebanyak $430 \mathrm{KK}$, sedangkan jumlah populasi petani di Kelurahan Pijoan adalah sebanyak 334 KK.Adapun jumlah sampel pada masing-masing desa ditentukan dengan metode Slovin dengan tingkat kesalahan yang dapat ditoleran (e) sebesar 15\%. Adapun rumus yang dipakai dalam menentukan ukuran sampel dari masing-masing populasi menurut slovin (wijaya, 2013) yaitu dirumuskan sebagai berikut: 


$$
\mathrm{n}=\frac{N}{1+N x(e)^{2}}
$$

Dimana :

$\mathrm{n}=$ ukuran atau jumlah sampel

$\mathrm{N}=$ jumlah populasi

e = presisi yang diharapkan (15\%).

Setelah dilakukan penarikan sampel maka selanjutnya penarikan jumlah petani yang akan dijadikan sebagai responden yang mewakili setiap desa, maka digunakan metode alokasi proposional yang ditentukan dengan rumus sebagai berikut:

$$
\mathrm{n}_{\mathrm{i}}=\frac{N i x n}{N}
$$

Dimana :

$\mathrm{n}_{\mathrm{i}}=$ jumlah responden desa ke-i

$\mathrm{N}_{\mathrm{i}}=$ jumlah sub populasi desa ke-i

$\mathrm{n}=$ jumlah sampel

$\mathrm{N}=$ jumlah populasi.

Dengan demikian maka diperoleh alokasi sampel seperti pada Tabel 5 berikut:

Tabel 1. Rincian Jumlah Populasi dan Sampel Petani Kelapa Sawit di Daerah Penelitian.

\begin{tabular}{cccc}
\hline No & Nama desa & Jumlah Populasi & Jumlah sampel \\
\hline 1 & Muhajirin & 430 & 25 \\
2 & Kelurahan Pijoan & 334 & 19 \\
\hline & Jumlah & 764 & 44 \\
\hline
\end{tabular}

Metode analisis data yang digunakan dalam penelitian ini adalah analisis deskriftif kuantitatif. Untuk mengetahui keuntungan usahatani kelapa sawit dapat digunakan formulasi sebagai berikut: (Soekartawi, 1995)

$\pi=\mathrm{TR}-\mathrm{TC}$

$\pi=(\mathrm{Y} . \mathrm{Py})-(\mathrm{TFC}+\mathrm{TVC})$

Dimana:

$\pi=$ Keuntungan usahatani kelapa sawit (Rp/tahun/ha)

$\mathrm{TR}=$ Total penerimaan usahatani kelapa sawit (Rp/tahun/ha)

$\mathrm{TC}=$ Total biaya usahatani kelapa sawit (Rp/tahun/ha)

$\mathrm{Y}=$ Produksi kelapa sawit $(\mathrm{Kg} / \mathrm{ha} / \mathrm{tahun})$

Py = Harga TBS $(\mathrm{Rp} / \mathrm{kg})$

TFC = Biaya tetap total (Rp/tahun)

TVC = Biaya variabel total $(\mathrm{Rp} /$ tahun/ha)

Jika menggunakan fungsi keuntungan atau supaya terbebas dari uji asumsi klasik maka digunakan analisis regresi linear berganda cobb-douglas unit output price (OUP),menurut Soekartawi (1990) untuk menganalisis faktor-faktor yang mempengaruhi keuntungan digunakan analisis regresi linier berganda (multiple regresion) dengan menggunakan fungsi keuntungan dalam bentuk bentuk Unit Output Price (UOP)sebagai berikut:

$$
\ln \pi=\operatorname{In} A+\beta_{1} \ln X_{1}+\beta_{2} \ln X_{2}+\beta_{3} \ln X_{3}+\beta_{4} \ln X_{4}+\beta_{5} \ln D+u
$$

\section{Dimana :}

$\pi=$ Keuntungan Usahatani padi kelapa sawit yang "dinormalkan" dengan harga produksi

In $\mathrm{A}=$ Intercept

$\mathrm{X}_{1} \quad$ = Biaya pupuk Urea yang "dinormalkan” dengan harga output

$\mathrm{X}_{2} \quad$ = Biaya pupuk Lain yang "dinormalkan" dengan harga output

$\mathrm{X}_{3} \quad$ = Biaya Tenaga Kerja yang "dinormalkan" dengan harga output 


$$
\begin{array}{ll}
\mathrm{X}_{4} \quad= & \text { Luas lahan yang "dinormalkan" dengan harga output } \\
\mathrm{D} & =\text { umur tanaman (Tahun) } \\
& \mathrm{D}=0 \text { apabila umur tanaman dibawah } 10 \text { tahun } \\
& \mathrm{D}=1 \text { apabila umur tanaman diatas } 10 \text { tahun } \\
\mathrm{u} \quad= & \text { Kesalahan }
\end{array}
$$

Untuk mengetahui besarnya proporsi atau persentase sumbangan variasi total keuntungan usahatani yang dijelaskan oleh setiap variabel secara bersama-sama, digunakan ukuran koefisien determinasi $\left(R^{2}\right)$ yang dapat diukur dengan rumus sebagai berikut:

$\mathrm{R}^{2}=\frac{b_{i} \Sigma x_{i} y_{i}}{\Sigma y_{i}^{2}}$

$$
\text { Dimana : }
$$

$\mathrm{R}^{2} \quad$ : koefisien determinasi berganda

$\mathrm{x}_{\mathrm{i}} \quad$ : jumlah variabel deviasi ke $-\mathrm{i}$ dari rata-rata $\left(\mathrm{x}_{\mathrm{i}}-\mathrm{x}\right)$

$y_{i} \quad$ : jumlah simpangan suatu variabel dari nilai rata-rata $\left(y_{i}-y\right)$

bi : koefisien regresi ke $-\mathrm{i}$

$y_{i}^{2} \quad$ : kuadrat simpangan suatu variabel ke-i dari nilai rata-rata $\left(y_{i}-y\right)^{2}$

Nilai $R^{2}$ dinamakan koefisien determinasi atau koefisien penentu, nilai $R^{2}$ berkisar antara 0 dan 1 yaitu $0 \leq R^{2} \leq 1$. Makin mendekati 1 nilai $R^{2}$ berarti semakin kuat hubungan yang terdapat antara variabel terikat dengan variabel bebas.

Menurut Hasan (2004), untuk mengetahui besarnya pengaruh variabel bebas terhadap variabel terikat dapat diuji dengan menggunakan uji $F$, dengan rumus sebagai berikut:

$\mathrm{F}_{\text {hitung }}=\frac{K T-\text { Regres } i}{K T-\text { Residu }}$

Dengan kriteria pengujian :

$\mathrm{H}_{0}$ diterima ( $\mathrm{H}_{1}$ ditolak), apabila $\mathrm{F}_{\text {hitung }} \leq \mathrm{F}_{\text {tabel }}(\alpha, \mathrm{k} ; \mathrm{n}-\mathrm{k}-1)$

$\mathrm{H}_{0}$ ditolak ( $\mathrm{H}_{1}$ diterima) apabila $\mathrm{F}_{\text {hitung }}>\mathrm{F}_{\text {tabel }}(\alpha, \mathrm{k} ; \mathrm{n}-\mathrm{k}-1)$

Sedangkan untuk mengetahui pengaruh masing-masing variabel terhadap keuntungan usahatani kelapa sawit dapat diuji dengan menggunakan uji $t$, dengan rumus sebagai berikut :

$\mathrm{T}_{\text {hitung }}=\frac{b i}{S b i}$

Dimana :

$b_{i}=$ koefisien regresi variabel ke-i

$\mathrm{S}_{\mathrm{bi}}=$ standar error perkiraan ke-i

$\mathrm{I}=1,2,3, \ldots .$.

Nilai t hitung yang didapat selanjutnya dibandingkan dengan $t$ tabel pada derajat kebebasan (df) tertentu dengan tingkat keyakinan tertentu dengan keputusan sebagai berikut:

$\mathrm{t}_{\text {hiung }}>\mathrm{t}_{\text {tabel }} \longrightarrow \mathrm{H}_{\mathrm{o}}$ ditolak

$\mathrm{t}_{\text {hiung }} \leq \mathrm{t}_{\text {tabel }} \longrightarrow \mathrm{H}_{\mathrm{o}}$ diterima

\section{HASIL DAN PEMBAHASAN}

\section{Identitas Responden}

Identitas responden yang dibutuhkan dalam penelitian ini adalah petani kelapa sawit yang meliputi: umur, pendidikan, pengalaman berusahatani, jumlah anggota keluarga dan status kepemilikan lahan.

Sebaran umur petani responden di daerah penelitian berada pada umur yang memiliki kemampuan fisik yang baik dan produktif, yaitu selang umur $28-59$ tahun. Ini berarti para petani mempunyai kemampuan untuk bekerja secara maksimal untuk 
mengelola usahataninya. Selain itu, pada kondisi umur petani seperti ini memiliki kemampuan fisik yang mendukung dalam upaya peningkatan usahataninya, sehingga memungkinkan untuk lebih mudah menerima atau menerapkan inovasi baru. Menurut Hernanto, (1991) menyatakan bahwa pada umumnya petani yang lebih muda dan sehat mempunyai kemampuan fisik lebih dinamis sehingga cepat mendapatkan pengalamanpengalaman baru yang berharga bagi perkembangan hidupnya dimasa yang akan datang.

Tingkat pendidikan petani sampel pada usahatani kelapa sawit di daerah penelitian rata-rata hanya tamat sekolah dasar (SD) dan sekolah lanjutan tingkat pertama (SLTP). Hal ini menunjukkan bahwa tingkat pendidikan di daerah penelitian masih tergolong rendah, tingkat pendidikan yang rendah ini memberikan pengaruh kurang baiknya petani dalam mengadopsi teknologi baru. Semakin tinggi tingkat pendidikan tentunya akan memiliki wawasan pemikiran yang relatif luas dan bertindak lebih selektif dalam mengembangkan usahatani kelapa sawit, petani yang berpendidikan umumnya lebih mudah menerima inovasi baru dan memanfaatkan potensi sumber daya alam yang ada secara optimal.

Lamanya pengalaman berusahatani kelapa sawit akan berpengaruh terhadap keputusan yang akan diambil, terutama yang berkaitan dengan pengelolaan usahatani itu sendiri. Semakin lama petani mengelola usahataninya, maka usahatani itu diharapkan semakin berhasil, lamanya pengalaman berusahatani kelapa sawit petani responden terbanyak pada tingkat 3-8 tahun.

Jumlah anggota keluarga yang dimaksud dalam penelitian ini adalah banyaknya anggota keluarga yang berada dalam rumah tangga petani yang terdiri dari ayah, ibu dan anak yang masih menjadi tanggungan keluarga. Di daerah penelitian petani sampel memiliki anggota keluarga yang paling dominan yaitu berkisar antara $4-5$ orang, Jumlah tanggungan yang lebih besar tentu menuntut pemenuhan kebutuhan keluarga yang lebih besar pula, hal ini akan mempengaruhi petani dalam kegiatan meningkatkan usahataninya

Petani responden pada daerah penelitian 100 persen merupakan petani yang memiliki lahan sendiri, menurut hasil wawancara ada beberapa petani yang membeli lahan kosong atau belukar selanjutnya ditanami kelapa sawit. Selain itu ada juga yang memiliki lahan dari hasil warisan maupun hibah dari orang tua responden sendiri. Sebagian besar lahan di dalam penelitian ini adalah alih fungsi lahan yaitu yang semula merupakan kebun karet diubah menjadi kebun kelapa sawit.

\section{Keadaan Usahatani}

Kecamatan Jambi Luar Kota merupakan salah satu daerah penghasil Tandan Buah Segar (TBS) kelapa sawit di Kabupaten Muaro Jambi. Usahatani kelapa sawit di daerah penelitian dibudidayakan dengan tujuan untuk mendapatkan hasil yang optimal guna menambah pendapatan petani, kegiatan panen yang dilakukan oleh petani di daerah penelitian adalah dimulai dari memotong pelepah daun, memotong tandan buah yang telah matang, dan terakhir mengangkut TBS ke tempat pengumpulan hasil sebelum dilakukannya penimbangan buah. Bibit yang digunakan dalam penanaman kelapa sawit di daerah penelitian rata-rata menggunakan bibit marihat dan sofindo. Rata -rata produksi sawit yang diperoleh petani swadaya sebesar $23.026 \mathrm{Kg} / \mathrm{Ha} / \mathrm{Tahun}$.

Menurut Mubyarto (1989) luas lahan mempengaruhi petani dalam mengelola usahataninya. Luas lahan merupakan ukuran potensial ekonomi petani untuk mengelola usahataninya, luas lahan yang dimaksud dalam penelitian ini adalah luas lahan garapan yang sudah dikonversi dan dikelola oleh petani sampel dan keluarganya dalam kegiatan 
berusahatani kelapa sawit. Adapun rata-rata luas lahan di daerah penelitian seluas 3,03 hektar. Menurut Hernanto (1991), dengan lahan usahatani yang sempit, akan membatasi petani berbuat pada rencana yang lebih lapang. Dengan demikian luas lahan yang banyak dan lahan tersebut dikelola dengan baik maka petani akan memperoleh hasil yang tinggi.

Rata-rata produksi TBS yang diperoleh petani di daerah penelitian adalah sebesar 76.996,36 Kg/tahun. Produksi terendah $17.640 \mathrm{Kg} /$ tahun dan produksi tertinggi $720.000 \mathrm{Kg} /$ tahun.Biaya pada usahatani kelapa sawit diartikan sebagai besarnya biaya yang dikeluarkan oleh petani di daerah penelitian dalam mengelola tanaman kelapa sawit miliknya, biaya digolongkan atas dua yaitu biaya tetap dan biaya variabel. Menurut Hernanto (1991), yang tergolong dalam biaya tetap yaitu pajak, penyusutan alat pertanian, penyusutan bangunan pertanian. Dalam penelitian ini yang tergolong biaya tetap adalah biaya penyusutan alat dan biaya sewa lahan. Sedangkan biaya variabel merupakan biaya yang berubah-ubah dan besar kecilnya biaya tergantung pada biaya skala produksi. Biaya variabel dalam penelitian ini meliputi biaya pupuk, biaya obatobatan, biaya tenaga kerja (tenaga kerja luar keluarga dan tenaga kerja dalam keluarga). Berikut merupakan biaya-biaya bagi petani dalam pengelolaan usahatani kelapa sawit.

Tabel 2. Rata-rata Total Biaya Pada Usahatani Kelapa Sawit (Swadaya Murni) di Kecamatan Jambi Luar Kota Kabupaten Muaro Jambi Tahun 2016

\begin{tabular}{llll}
\hline & Uraian & $\begin{array}{c}\text { Biaya } \\
\text { (Rp/Petani/Tahun) }\end{array}$ & $\begin{array}{c}\text { Biaya } \\
\text { (Rp/Petani/Ha/tahun) }\end{array}$ \\
\hline 1. Biaya Tetap & & \\
a. Penyusutan Alat & 268.884 & 118.631 \\
b. Sewa Lahan & 6.068 .182 & 2.000 .000 \\
2. Biaya Variabel & & \\
a. Pupuk & 14.066 .609 & 3.719 .876 \\
b. Obat-obatan & 826.455 & 228.206 \\
c. TK. Dalam Keluarga & 5.618 .635 & 2.539 .975 \\
d. TK. Luar Keluarga & 6.305 .360 & 1.081 .559 \\
\hline & Total Biaya & $\mathbf{3 3 . 1 5 4 . 1 2 5}$ & $\mathbf{9 . 6 8 8 . 2 4 7}$ \\
\hline
\end{tabular}

Tabel 2 menunjukkan bahwa rata-rata biaya yang terbesar pada usahatani kelapa sawit adalah biaya pupuk dan rata-rata biaya yang terkecil pada biaya penyusutan alat, baik pada biaya per petani maupun biaya per hektar. Adapun rata-rata total biaya usahatani kelapa sawit per petani adalah sebesar Rp.33.154.125/Tahun. Sedangkan rata-rata total biaya per hektar adalah sebesar Rp.9.688.247/Ha/Tahun.

Penerimaan atau nilai produksi yaitu jumlah produksi dikalikan harga produksi dengan satuan rupiah, sedangkan pendapatan petani yaitu selisih antara penerimaan dengan total biaya per usahatani dengan satuan rupiah dan keuntungan merupakan pendapatan dikurangi upah tenaga kerja keluarga dan bunga modal sendiri per usahatani dengan satuan rupiah. (suratiyah, 2011) Jumlah penerimaan yang akan diterima dari petani dalam penelitian ini dapat ditentukan dengan mengalikan jumlah produksi TBS pertahun dengan harga TBS pertahun. Sedangkan biaya produksi yang dikeluarkan yaitu biaya tenaga kerja (dalam dan luar keluarga), sewa lahan, biaya pupuk, biaya obat-obatan dan biaya penyusutan alat usahatani.

keuntungan yang dihitung Dalam penelitian ini merupakan keuntungan yang diperoleh dari penerimaan dikurangi dengan total biaya (biaya tetap dan biaya variabel, termasuk pula biaya tenaga kerja keluarga dan biaya sewa lahan). 
Tabel 3. Total Rata-rata Biaya dan Keuntungan Usahatani Kelapa Sawit (Swadaya Murni) di Kecamatan Jambi Luar Kota Kabupaten Muaro Jambi Tahun 2016

\begin{tabular}{clcc}
\hline No & \multicolumn{1}{c}{ Uraian } & $\begin{array}{c}\text { Biaya } \\
\text { (Rp/Petani/Tahun) }\end{array}$ & $\begin{array}{c}\text { Biaya } \\
\text { (Rp/Petani/Ha/Tahun) }\end{array}$ \\
\hline 1 & Biaya Produksi & 268.884 & 118.631 \\
& Penyusutan Alat & 6.068 .182 & 2.000 .000 \\
& Sewa Lahan & 14.066 .609 & 3.719 .876 \\
& Biaya Pupuk & 826.455 & 228.206 \\
& Biaya Obat-obatan & 5.618 .635 & 2.539 .975 \\
& Biaya TK.Dalam Keluarga & 6.305 .360 & 1.081 .559 \\
& Biaya TK.Luar Keluarga & 33.154 .125 & 9.688 .247 \\
2 & Total Biaya Produksi & 76.996 & 23.027 \\
3 & Jumlah Produksi & 1.100 & 1.100 \\
4 & Harga & 84.696 .000 & 25.329 .424 \\
5 & Penerimaan & 63.228 .692 & 20.181 .152 \\
6 & Pendapatan & 51.541 .875 & 15.641 .177 \\
\hline 7 & Keuntungan & & \\
\hline
\end{tabular}

Tabel 3 menunjukkan bahwa rata-rata penerimaan petani dari usahatani kelapa sawit (swadaya murni) per petani selama setahun sebesar Rp.84.696.000/Tahun, sedangkan rata-rata penerimaan per hektarnya selama setahun sebesar Rp.25.329.424/Ha/Tahun. Biaya total rata-rata pembiayaan secara ekonomi per petani selama setahun sebesar Rp.33.154.125/Tahun, sedangkan rata-rata total biaya per hektar selama setahun sebesar Rp. 9.688.247/Ha/Tahun. Sehingga diperoleh rata-rata keuntungannya per petaninya sebesar Rp.51.541.875/Tahun dan rata-rata keuntungannya per hektar sebesar Rp.15.641.177/Ha/Tahun.

Untuk mengetahui faktor-faktor yang mempengaruhi keuntungan usahatani kelapa sawit (swadaya murni), analisis selanjutnya dilakukan dengan regresi linier berganda (Eviews 8).Dalam penelitian ini, faktor-faktor yang diduga mempengaruhi keuntungan usahatani kelapa sawit (swadaya murni) adalah biaya pupuk urea, biaya pupuk lain (non urea), biaya tenaga kerja, luas lahan, dan umur tanaman.

Tabel 4. Pengaruh Faktor-Faktor Keuntungan Pada Usahatani Kelapa Sawit (Swadaya Murni) Tahun 2016

\begin{tabular}{lclll}
\hline \hline \multicolumn{1}{c}{ Variable } & Coefficient & Std. Error & t-Statistic & Prob. \\
\hline \hline LN X1 & -0.191642 & 0.081849 & -2.341424 & 0.0246 \\
LN X2 & -0.103454 & 0.036066 & -2.868472 & 0.0067 \\
LN X3 & 0.771222 & 0.163875 & 4.706167 & 0.0000 \\
LN X4 & 0.596312 & 0.208531 & 2.859578 & 0.0069 \\
LN DUMMY & 0.014794 & 0.007118 & 2.078334 & 0.0445 \\
$\quad$ C & 1.105614 & 0.406558 & 2.719452 & 0.0098 \\
\hline \hline R-squared & 0.959727 & Mean dependent var & 10.32247 \\
Adjusted R-squared & 0.954428 & S.D. dependent var & 0.826228 \\
S.E. of regression & 0.176381 & Akaike info criterion & -0.506219 \\
Sum squared resid & 1.182187 & Schwarz criterion & -0.262921 \\
Log likelihood & 17.13682 & Hannan-Quinn criter. & -0.415992 \\
F-statistic & 181.1105 & Durbin-Watson stat & 1.847592 \\
Prob(F-statistic) & 0.000000 & & \\
\hline
\end{tabular}


Pada Tabel 4 di atas menunjukkan bahwa hasil analisis sidik ragam diperoleh $F_{\text {hitung }}$ sebesar 181.1105 dan $F_{\text {Tabel }}$ sebesar 2,48 pada taraf 95,4 \% (Prob F- Static 0,0000). $\mathrm{Hal}$ ini berarti model penduga digunakan memiliki akurasi (kehandalan yang sangat nyata). Model hasil pendugaan jika dipergunakan untuk melakukan pendugaan pengaruh biaya pupuk urea, biaya pupuk lain, tenaga kerja, luas lahan dan umur tanaman akan dapat menjelaskan secara nyata terhadap variasi tinggi rendahnya keuntungan kelapa sawit (swadaya murni). Selanjutnya berdasarkan hasil analisis diatas diperoleh nilai Durbin Watson sebesar 1,847 , yang mana nilai ini setelah dibandingkan dengan Tabel DW berada pada rentang yang ditolerir yaitu lebih besar dari nilai DU sebesar 1,78 dan lebih kecil dari nilai DL sebesar 2,22. Hal ini berarti model penduga bebas dari kesalahan uji statistik yaitu uji autokorelasi.

Berdasarkan analisis regresi diperoleh nilai koefisien determinasi (Adjusted Rsquared) sebesar 0,95442. Nilai tersebut mengartikan bahwa 95,44\% variasi dependen (keuntungan) mampu dijelaskan secara bersama-sama oleh variabel independen (biaya pupuk urea, biaya pupuk lain, biaya tenaga kerja, luas lahan dan umur tanaman) yang dimasukkan kedalam persamaan pada tingkat kepercayaan 95,44\%. Sedangkan sisanya 4,64\% disebabkan oleh pengaruh lainnya.

Berdasarkan Tabel di atas maka bentuk hubungan matematis fungsi keuntungan kelapa sawit (swadaya murni) di daerah penelitian dituliskan sebagai berikut:

$\operatorname{Ln} \pi=1,1060,191 \operatorname{Ln} X_{1}-0,103 \operatorname{Ln} X_{2}+0,771 \operatorname{Ln} X_{3}+0,596 \operatorname{Ln} X_{4}+0,014 \operatorname{Ln} D$

Atau

$Y=1,106 \times 1^{0,191} \cdot X 2^{0,103} \cdot X 3^{0,771} \cdot X 4^{0,596} \cdot D^{0,014}$

Untuk lebih mengetahui pengaruh biaya pupuk urea $\left(X_{1}\right)$, biaya pupuk lain $\left(X_{2}\right)$, biaya tenaga kerja $\left(\mathrm{X}_{3}\right)$, luas lahan $\left(\mathrm{X}_{4}\right)$ dan umur tanaman $(D)$ secara individu, dapat dilihat pada interpretasi atau uraian dengan menggunakan uji t-hitung dan t-tabel sebagai berikut:

\section{Pengaruh Biaya Pupuk Urea $\left(X_{1}\right)$ Terhadap Keuntungan Usahatani Kelapa Sawit (Swadaya Murni)}

Sebaran biaya pupuk urea $\left(\mathrm{X}_{1}\right)$ dari Rp.1.123.300 sampai Rp.86.016.000 dengan rata-rata biaya pupuk urea sebesar Rp.7.838.518, serta besarnya simpangan baku 0,082. Koefisien regresi $\left(b_{i}\right)$ untuk biaya pupuk urea $\left(X_{1}\right)$ negatif, yang berarti bahwa semakin banyak biaya pupuk yang dikeluarkan oleh petani untuk merangsang produksi kelapa sawit maka keuntungan usahatani kelapa sawit akan menurun. Untuk itu biaya yang dikeluarkan untuk pupuk sebaiknya disesuaikan dengan kebutuhan tanaman kelapa sawit.

Berdasarkan hasil regresi linier berganda dapat ditentukan bahwa variabel biaya pupuk urea $\left(\mathrm{X}_{1}\right)$ mempunyai koefisien sebesar $-0,191$ yang mempunyai pengaruh negatif, artinya apabila terjadi kenaikan dalam biaya pupuk urea sebesar $1 \%$, maka akan bepengaruh terhadap penurunan keuntungan petani kelapa sawit (swadaya murni) sebesar 0,191\%.

Taraf signifikansi biaya pupuk urea $\left(X_{1}\right)$ sebesar 0,0246 lebih kecil dari 0,05 yang artinya signifikan secara statistik terhadap keuntungan petani. Dengan menggunakan uji statistik, variabel biaya pupuk urea mempunyai nilai t-hitung sebesar 2,341 lebih besar dari t-tabel sebesar 2,024 (t-hitung $>\mathrm{t}$-tabel), maka $\mathrm{H}_{0}$ ditolak $\mathrm{H}_{1}$ diterima, artinya bahwa variabel biaya pupuk urea $\left(\mathrm{X}_{1}\right)$ berpengaruh nyata terhadap keuntungan usahatani kelapa sawit (swadaya murni). 
Hal ini sejalan dengan penelitian Kunaifi (2008), biaya pupuk berpengaruh nyata terhadap pendapatan usahatani kelapa sawit di kecamatan merlung. Biaya pupuk mempunyai angka signifikan dibawah $0,05(0,001)$ karena itu secara signifikan biaya pupuk mempengaruhi pendapatan usahatani kelapa sawit.

\section{Pengaruh Biaya Pupuk Lain $\left(\mathrm{X}_{2}\right)$ Terhadap Keuntungan Usahatani Kelapa Sawit (Swadaya Murni)}

Sebaran biaya pupuk lain $\left(X_{2}\right)$ dari Rp.810.00 sampai Rp.69.750.000 dengan ratarata biaya pupuk lain sebesar Rp.6.228.091, serta besarnya simpangan baku 0,036. Berdasarkan hasil regresi linier berganda dapat ditentukan bahwa variabel biaya pupuk lain $\left(\mathrm{X}_{2}\right)$ mempunyai koefisien sebesar $-0,103$ yang mempunyai pengaruh negatif, artinya apabila terjadi kenaikan dalam biaya pupuk lain sebesar $1 \%$, maka akan bepengaruh terhadap penurunan keuntungan petani kelapa sawit (swadaya murni) sebesar 0,103\%.

Taraf signifikansi biaya pupuk lain $\left(\mathrm{X}_{2}\right)$ sebesar 0,0067 lebih kecil dari 0,05 yang artinya signifikan secara statistik terhadap keuntungan petani. Dengan menggunakan uji statistik, variabel biaya pupuk lain mempunyai nilai t-hitung sebesar 2,868 lebih besar dari t-tabel sebesar 2,024 (t-hitung > t-tabel), maka $\mathrm{H}_{0}$ ditolak $\mathrm{H}_{1}$ diterima, artinya bahwa variabel biaya pupuk lain $\left(\mathrm{X}_{2}\right)$ berpengaruh nyata terhadap keuntungan usahatani kelapa sawit (swadaya murni).

Hal ini sejalan dengan penelitian Kunaifi (2008), biaya pupuk berpengaruh nyata terhadap pendapatan usahatani kelapa sawit di kecamatan merlung. Biaya pupuk mempunyai angka signifikan dibawah $0,05(0,001)$ karena itu secara signifikan biaya pupuk mempengaruhi pendapatan usahatani kelapa sawit.

\section{Pengaruh Biaya Tenaga Kerja $\left(X_{3}\right)$ Terhadap Keuntungan Usahatani Kelapa Sawit (Swadaya Murni)}

Sebaran biaya tenaga kerja $\left(\mathrm{X}_{3}\right)$ dari Rp.2.588.800 sampai Rp.98.880.000 dengan rata-rata biaya tenaga kerja sebesar Rp.11.923.995, serta besarnya simpangan baku 0,163 . Koefisien regresi $\left(b_{i}\right)$ untuk biaya tenaga kerja $\left(X_{3}\right)$ positif, yang berarti bahwa dengan penambahan biaya tenaga kerja terjadi penambahan dalam keuntungan bagi petani, hal ini dikarenakan curahan tenaga kerja baik tenaga kerja dalam keluarga maupun luar keluarga terhadap usahatani kelapa sawit memberikan peningkatan terhadap keuntungan berusahatani. Semakin terorganisir dan terlaksana dengan baik kegiatan-kegiatan dalam berusahatani kelapa sawit seperti pemupukan, penyemprotan dan pemanenan, maka tanaman kelapa sawit akan berproduksi secara normal serta produktivitas semakin meningkat atau baik. Sehingga secara langsung dengan peningkatan produksi mengakibatkan total penerimaan akan semakin bertambah.

Berdasarkan hasil regresi linier berganda dapat ditentukan bahwa variabel biaya tenaga kerja $\left(X_{3}\right)$ mempunyai koefisien sebesar 0,771 yang mempunyai pengaruh positif, artinya apabila terjadi kenaikan dalam biaya tenaga kerja sebesar $1 \%$, maka akan bepengaruh terhadap kenaikan keuntungan petani kelapa sawit (swadaya murni) sebesar $0,771 \%$.

Taraf signifikansi biaya tenaga kerja $\left(\mathrm{X}_{3}\right)$ sebesar 0,0000 lebih kecil dari 0,05 yang artinya signifikan secara statistik terhadap keuntungan petani. Dengan menggunakan uji statistik, variabel biaya tenaga kerja mempunyai nilai t-hitung sebesar 4,706 lebih besar dari t-tabel sebesar 2,024 (t-hitung > t-tabel), maka $\mathrm{H}_{0}$ ditolak $\mathrm{H}_{1}$ diterima, artinya bahwa variabel biaya tenaga kerja $\left(X_{3}\right)$ berpengaruh nyata terhadap keuntungan usahatani kelapa sawit (swadaya murni). 
Hal ini sejalan dengan pernyataan Mosher dalam Suratiyah (2011), petani berperan sebagai manajer dan juru tani, petani sebagai manajer akan berhadapan dengan berbagai alternatif yang harus diputuskan mana yang harus dipilih untuk diusahakan, menetukan cara-cara berproduksi, menentukan cara-cara pembelian sarana produksi, menghadapi persoalan tentang biaya, mengusahakan permodalan dan sebagainya. Selanjutnya hal ini tidak sejalan dengan penelitian Kunaifi (2008), biaya tenaga kerja tidak berpengaruh nyata terhadap pendapatan usahatani kelapa sawit.

\section{Pengaruh Luas Lahan $\left(\mathbf{X}_{4}\right)$ Terhadap Keuntungan Usahatani Kelapa Sawit (Swadaya Murni)}

Sebaran luas lahan $\left(\mathrm{X}_{4}\right)$ dari 1 Ha sampai 17 Ha dengan rata-rata luas lahan sebesar $3 \mathrm{Ha}$, serta besarnya simpangan baku 0,208. Berdasarkan hasil regresi linier berganda dapat ditentukan bahwa variabel luas lahan $\left(\mathrm{X}_{4}\right)$ mempunyai koefisien sebesar 0,596 yang mempunyai pengaruh positif, artinya apabila terjadi kenaikan dalam luas lahan sebesar $1 \%$, maka akan bepengaruh terhadap kenaikan keuntungan petani kelapa sawit (swadaya murni) sebesar 0,596\% dengan asumsi faktor lain dianggap tetap.

Taraf signifikansi luas lahan $\left(\mathrm{X}_{4}\right)$ sebesar 0,0069 lebih kecil dari 0,05 yang artinya signifikan secara statistik terhadap keuntungan petani. Dengan menggunakan uji statistik, variabel luas lahan mempunyai nilai t-hitung sebesar 2,859 lebih besar dari ttabel sebesar 2,024 (t-hitung > t-tabel), maka $\mathrm{H}_{0}$ ditolak $\mathrm{H}_{1}$ diterima, artinya bahwa variabel luas lahan $\left(\mathrm{X}_{4}\right)$ berpengaruh nyata terhadap keuntungan usahatani kelapa sawit (swadaya murni). Dari hasil tersebut menunjukkan bahwa penambahan luas lahan didaerah penelitian secara individu berpengaruh nyata terhadap keuntungan usahatani kelapa sawit (swadaya murni).

Hal ini sejalan dengan teori menurut Suratiyah (2011), menyatakan bahwa dipandang dari sudut efisiensi semakin luas lahan yang diusahakan maka semakin tinggi produksi dan pendapatan per satuan luasnya. Sedangkan menurut Hernanto (1991), yang menyatakan bahwa dengan lahan usahatani sempit, akan membatasi petani berbuat pada rencana yang lebih lapang. Tanah yang sempit dengan kualitas tanah yang kurang baik akan merupakan beban bagi petani pengelola usahatani. Selanjutnya hal ini sejalan dengan Muttakin (2014), luas lahan garapan berpengaruh sangat nyata terhadap pendapatan, artinya setiap terjadi peningkatan luas lahan garapan maka terjadi peningkatan pendapatan.

\section{Dummy (Umur Tanaman)}

Sebaran umur tanaman (D) dari 4 tahun sampai 15 tahun dengan rata-rata umur tanaman kelapa sawit petani (swadaya murni) 8 tahun, sedangkan besarnya simpangan baku untuk umur tanaman sebesar 0,007. Berdasarkan hasil regresi linier berganda dapat ditentukan bahwa variabel umur tanaman (D) mempunyai koefisien sebesar 0,014 yang mempunyai pengaruh positif, artinya apabila terjadi kenaikan dalam umur tanaman sebesar $1 \%$, maka akan bepengaruh terhadap kenaikan keuntungan petani kelapa sawit (swadaya murni) sebesar $0,014 \%$ dengan asumsi faktor lain dianggap tetap.

Taraf signifikansi variabel dummy (D) sebesar 0,0445 lebih kecil dari 0,05 yang artinya signifikan secara statistik terhadap keuntungan petani. Dengan menggunakan uji statistik, variabel dummy mempunyai nilai t-hitung sebesar 2,078 lebih besar dari t-tabel sebesar 2,024 (t-hitung > t-tabel), maka $\mathrm{H}_{0}$ ditolak $\mathrm{H}_{1}$ diterima, artinya bahwa variabel dummy (D) berpengaruh nyata terhadap keuntungan usahatani kelapa sawit (swadaya murni). Dari hasil tersebut menunjukkan bahwa variabel dummy (umur tanaman) 
didaerah penelitian secara individu berpengaruh nyata terhadap keuntungan usahatani kelapa sawit (swadaya murni).

Hal ini sejalan dengan pernyataan Drajat dalam Darsiti (2014), dalam penelitiannya mengatakan bahwa umur tanaman mempengaruhi kualitas rendemen TBS, yang pada akhirnya sangat berpengaruh terhadap harga TBS. Kualitas rendemen TBS dikatakan tinggi ketika tanaman berumur pada selang waktu 7 hingga 22 tahun sehingga perkiraan harga TBS akan tinggi. Selanjutnya hal ini sejalan dengan Darsiti (2014), berdasarkan hasil analisis regresi linear berganda menunjukkan bahwa variabel umur tanaman mempunyai pengaruh yang positif terhadap pendapatan usahatani kelapa sawit.

\section{KESIMPULAN}

Berdasarkan hasil penelitian diperoleh rata-rata biaya yang dikeluarkan oleh petani sebesar Rp.33.154.125/tahun, sedangkan rata-rata biaya yang dikeluarkan oleh petani per hektarnya sebesar Rp.9.688.247/Ha/tahun, Dimana biaya terbesar yang dikeluarkan oleh petani yaitu biaya pemupukan sebesar Rp. 14.066.609/tahun dan biaya pemupukan per hektarnya sebesar Rp.3.719.876/Ha/tahun. Sedangkan rata-rata keuntungan usahatani kelapa sawit swadaya murni sebesar Rp.51.541.875/tahun, Dan rata-rata keuntungan usahatani kelapa sawit swadaya murni per hektarnya sebesar Rp.15.641.177/Ha/Tahun. Dari hasil penelitian diketahui bahwa faktor-faktor seperti biaya pupuk urea, biaya pupuk lain, biaya tenaga kerja, luas lahan dan umur tanaman (dummy) secara bersama-sama berpengaruh sangat nyata terhadap keuntungan usahatani kelapa sawit swadaya murni di daerah penelitian. Sedangkan secara parsial biaya pupuk urea dan biaya pupuk lain (non urea) berpengaruh negatif terhadap keuntungan usahatani kelapa sawit swadaya murni.

\section{UCAPAN TERIMAKASIH}

Penulis sampaikan ucapan terimakasih kepada Dekan Fakultas Pertanian Universitas Jambi dan Ketua Program Studi Agribisnis Fakultas Pertanian Universitas Jambi yang telah memfasilitasi pelaksanaan penelitian ini. Ucapan terima kasih kepada Bapak Kepala Desa Muhajirin Kecamatan Jambi Luar Kota Kabupaten Muaro Jambi dan Bapak Lurah Pijoan Kecamatan Jambi Luar Kota Kabupaten Muaro Jambi yang sangat membantu serta memberikan data bagi penulis sehingga penulis dapat menyelesaikan artikel ini.

\section{DAFTAR PUSTAKA}

Badan Pusat Statistika Indonesia, 2013. Luas Tanaman Perkebunan Besar Menurut Jenis Tanaman, Indonesia.

2013. Katalog BPS (Statistik Kelapa Sawit Indonesia). Badan Pusat Statistik (tidak untuk dipublikasikan).Jakarta.

Darsiti, 2014. Analisis Pendapatan Usahatani Kelapa sawit Berdasarkan Pola Pengusahaan Di Kecamatan Renah Mendaluh Kabupaten Tanjung Jabung Barat. Skripsi Fakultas Pertanian Universitas Jambi. Jambi.

Hernanto Fadholi, 1991. Ilmu Usaha Tani. Penebar Swadaya. Jakarta.

Kunaifi Aang, 2008. Analisis Faktor-faktor yang Mempengaruhi Pendapatan Usahatani Kelapa Sawit Peserta PIR-TRANS PT. Inti Indosawit Subur di Kecamatan Merlung. Skripsi Fakultas Pertanian Universitas Jambi (tidak dipublikasikan). Jambi.

Mubyarto, 1989. Pengantar Ekonomi Pertanian. LP3S. Jakarta. 
JURNAL ILMIAH SOSIO-EKONOMIKA BISNIS

ISSN: 1412-8241 (p); 2621-1246 (e), Volume 21. no (1) 2018

DOI: $10.22437 /$ jiseb.v21i1

Muttakin Dedi, 2013. Faktor-faktor Sosial Ekonomi Yang Mempengaruhi Pendapatan Usahatani Kelapa Sawit Pola Swadaya Di Desa Kepau Jaya Kabupaten Kampar. Jurnal Ilmiah Fakultas Pertanian Universitas Islam Riau. Riau.

Soekartawi, 1990. Teori Ekonmoni Produksi dengan Pokok Bahasan Analisis Fungsi Cobb - Douglas. Rajawali Pers. Jakarta.

1995. Teori Agribisnis Dan Aplikasinya. PT. Rajawali Grapindo Persada. Jakarta.

Suratiyah Ken, 2011. Ilmu Usaha Tani. Penebar Swadaya. Jakarta

Wijaya Tony, 2013. Metodologi Penelitian Ekonomi dan Bisnis. Graha Ilmu. Yogyakarta 